\title{
EVALUATION OF WARFARIN KNOWLEDGE IN PATIENTS WITH CHRONIC ATRIAL FIBRILLATION IN OUTPATIENT CARDIOVASCULAR CLINICS AT SPECIALIZED MEDICAL HOSPITAL
}

\author{
${ }^{1}$ Mohamed Elsayed Hamed Elzeky, ${ }^{2}$ Wafaa Ismail Sherief, ${ }^{3}$ Amany Mohamed \\ Shebl Abd Ellateef, and ${ }^{4}$ Hanan Mohamed Mohamed Soliman. \\ 1,2,3,4 Medical-Surgical Nursing Department, Faculty of Nursing-Mansoura University \\ E-mail of corresponding author: moh.hamed69@yahoo.com
}

\begin{abstract}
:
Atrial fibrillation is a major risk factor of stroke. Stroke prevention in atrial fibrillation (AF), most commonly with warfarin, requires maintenance of a narrow therapeutic target (INR 2.0 to 3.0). To ensure safe and effective use, it is vital that patients have a sound understanding of warfarin. Therefore, the aim of the study was to determine AF patient's knowledge about using warfarin. Methods descriptive correlational cross sectional research design was conducted in the cardiovascular outpatient clinics of Specialized Medical Hospital at Mansoura University. Sociodemographic data sheet \& Warfarin knowledge questionnaire was designed after an extensive literature review. It contains 24 questions related to warfarin use and international normalized ratio (INR) test. Convenient sample of this study composed of 104 adult patients of both sexes who met inclusion criteria and faceto-face interviews using standard questionnaires were administered to determine the demographic characteristics, medical history and the patient's knowledge of warfarin therapy. Results the result revealed that Patients' warfarin knowledge was poor, with an overall score of 9.9 \pm 6.32 (range 0-24). Knowledge deficits were greater in female subjects, older subjects, subjects with less formal education, subjects live in rural, subjects don't work and subjects with long duration of warfarin use. Conclusion There is an increasing need to introduce effective education programs to current patients in order to enhance and update their knowledge with regard to warfarin therapy and INR test.
\end{abstract}

Key words: Atrial Fibrillation, oral anticoagulant, warfarin, patient knowledge.

\section{Introduction:}

Atrial fibrillation is a chronic condition that is characterized by an irregular heartbeat. This irregularity of the heart rhythm places people with atrial fibrillation at greater risk of forming blood clots and subsequently increases their risk of stroke ${ }^{(1)}$. AF confers a 5-fold risk of stroke. Ischemic strokes in association with AF are often fatal, and those patients who survive are left more disabled by their stroke and more likely to suffer a recurrence than patients with other causes of stroke ${ }^{(2)}$.

Oral anticoagulation (OAC) significantly reduces the risk of stroke in atrial fibrillation (AF) patients ${ }^{(3)}$.Until recently the mainstay of OAC therapy was vitamin $\mathrm{K}$ antagonists, most commonly with warfarin. However, warfarin requires $\mathrm{AF}$ patients to maintain a narrow therapeutic range (INR range 2.0 to3.0) (4).Unwanted serious complications most likely occur when patients are over anticoagulated or underanticoagulated. So it requires frequent monitoring of patient's INR and dose adjustments to ensure minimizing the risk of thromboembolic events without increasing the risk of bleeding complications ${ }^{(5)}$. 


\begin{abstract}
Several factors contributing to fluctuation in INR and subsequently nontherapeutic treatment outcomes including interactions with other drugs, dietary intake, poor patient's compliance and deficiency in patient's knowledge ${ }^{(6)}$.

Studies suggest where patients have a greater knowledge of warfarin therapy, INR values are more often within target range ${ }^{(7)}$.Patient need information about the need for warfarin, the risks and benefits associated with OAC therapy, potential interactions with food, drugs, and alcohol, and the importance of monitoring, and control of their $\mathrm{INR}^{(8)}$.

Therefore, the patient's knowledge and education on warfarin therapy has an important impact on anticoagulation control and results in a more effective and stable treatment. Moreover, adherence to warfarin therapy is enhanced by knowledge and understanding of medications, its benefits and side effects ${ }^{(9}$, 10).
\end{abstract}

\section{Aim of study:}

Assess knowledge regarding warfarin among patients with chronic atrial fibrillation

\section{Research questions:}

1- What is the patient's current level of knowledge about warfarin?

2- What are factors that correlated with the AF patient's knowledge of warfarin therapy?

\section{Subjects \& Methods}

Study Design:

A descriptive correlational cross sectional research design was used in this study.

\section{Setting:}

This Study was conducted at the cardiovascular outpatient clinic in the Specialized-Medical Hospital at Mansoura University.

Subjects

A convenient sample of 104 patients with atrial fibrillation were entered in the study. The patients were selected based on the following criteria

\section{Inclusion criteria:}

Adult patients, of both sexes, 18 years old and less than 60 years,

Had at least two ECG-documented episodes of AF,

Diagnosed with AF 6 months ago, Participants should have been taking warfarin for at least 3 months, able to communicate and willing to participate in the study.

\section{Exclusion criteria:}

Malignant tumor or other diseases at the terminal stage,

The occurrence of myocardial infarction or thromboembolic events within 3 Months.

Thyroid dysfunction, Physical or mental limitations in completing the questionnaire Tools:

\section{Tool 1: warfarin knowledge questionnaire:}

The following tool were developed based on recent literature review and were utilized to collect data pertinent to the study and consisted of two parts $(16,17,18,20,24,26,34)$.

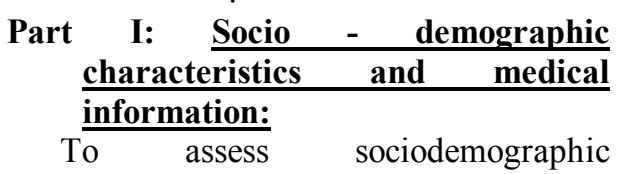
characteristics (e.g. age, gender, marital status, educational level, Occupation, treatment system and residence) and medical information (e.g. type of AF, duration of warfarin use previous bleeding and previous stroke).

Part II: patients' warfarin knowledge scale:

This part had (24) items that cover the main topics on warfarin such as purpose of warfarin, drug interactions, vitamin $\mathrm{K}$ and diet ,effect of missing dose and its management as well as when the patient should seek medical advice. All subjects need to respond "Yes," "No," to each question. A correct answer was scored =1; 
an incorrect answer was scored $=0$. Scores of each item were summed up, and the total score ranged from 0 to 24 . Score percentage $=$ mean score / maximum possible score $\times 100 \%$. Higher scores indicated more knowledge about AF. The level of knowledge was classified according to good, fair, and poor for overall knowledge. A score of $75 \%=(18-$ 24) were classified as "Good", from $74 \%$ to $50 \%=(12-17)$ classified as "fair", and a score $<50 \%=(0-11)$ was classified as "poor" (35).

\section{Methods:}

1. An official permission was issued from the faculty of nursing, Mansoura University to carry out the study.

2. An official letter was issued with approval from the director of the hospital after explanation of the purpose of the study and the schedule of data collection.

3. The tool was developed by the researcher after reviewing the related literature.

4. The tool was tested for content validity by a panel of 5 experts in the field of the study (4 were nurse professors working with faculty of nursing and medical - surgical nursing and medical field and the modification was done (simplified words used to be understood by patients).

5. Tool was tested for its reliability using the test - retest measurement and Cronbach,s alpha test. (Test - retest) reliability of knowledge questionnaire is ranged from $r=0.82-r=0.86$ and Cronbach,s alpha (r. alpha) $=0.868$.

6. Patient's written consent was obtained after explanation of the objective of the study and confidentiality and privacy was assured.
7. A pilot study was carried out on 10 patients to test feasibility, clarity and applicability of the tool. Accordingly modifications were done and final form of the tool was reconstructed and made ready for use.

8. Patient were selected according to inclusion criteria

9. An interview schedule was used for data collection and after the examination of the patient by the junior doctor the researcher took the patient from the clinic to the waiting room for his medications in outpatient clinic.

10. The researcher managed to interview from 3 to 5 patients daily time taken to fill study tools ranged from $20-30$ minutes on individual basis to be filled depending on the degree of understanding and response of the patient.

11. The researcher coded the questionnaires to assure the anonymity of the subjects. Finally, the researcher scored the responses, and compiled them for data analysis.

12. The data collection covered a period of 4 months, started from the beginning of October 2013 to the end of January 2014

\section{Results:}

The data collected were analyzed statistically and the results are categorized into 3 main parts which are: sociodemographic characteristics and medical information (table5.1, 5.2), knowledge of patients about anticoagulation (figure5.1, table 5.3), factors affect knowledge (table 5.4, 5.5). 
Table (5.1): Distribution of study populations according to their sociodemographic characteristics $(\mathrm{No}=104)$ :

\begin{tabular}{|c|c|c|}
\hline Itenus & $\begin{array}{c}\text { No } \\
\text { Nol }\end{array}$ & 96 \\
\hline $\begin{array}{l}\text { Age group: } \\
18-<30 \\
30<40 \\
40-<50 \\
50<00\end{array}$ & $\begin{array}{l}4 \\
3 \\
18 \\
79\end{array}$ & $\begin{array}{c}3.8 \\
2.9 \\
17.3 \\
76\end{array}$ \\
\hline $\begin{array}{l}\text { Gender : } \\
\text { Miale } \\
\text { Fermale }\end{array}$ & $\begin{array}{l}40 \\
64\end{array}$ & $\begin{array}{l}38.5 \\
61.5\end{array}$ \\
\hline $\begin{array}{l}\text { Marital status = } \\
\text { Single } \\
\text { Manried } \\
\text { Divorced } \\
\text { Widow }\end{array}$ & $\begin{array}{l}5 \\
83 \\
1 \\
15\end{array}$ & $\begin{array}{c}4.8 \\
79.8 \\
1 \\
14.4\end{array}$ \\
\hline $\begin{array}{l}\text { Edacational level = } \\
\text { Mliterate } \\
\text { Read \& nrite } \\
\text { Secondary } \\
\text { University }\end{array}$ & $\begin{array}{l}63 \\
20 \\
18 \\
3\end{array}$ & $\begin{array}{l}60.6 \\
19.2 \\
17.3 \\
2.9\end{array}$ \\
\hline $\begin{array}{l}\text { Working status = } \\
\text { Working } \\
\text { Office work } \\
\text { Manwal work } \\
\text { Not working } \\
\text { Student } \\
\text { House wife } \\
\text { Others }\end{array}$ & $\begin{array}{l}22 \\
5 \\
17 \\
82 \\
2 \\
61 \\
19\end{array}$ & $\begin{array}{l} \\
21.1 \\
4.8 \\
16.3 \\
78.9 \\
1.9 \\
58.7 \\
18.3\end{array}$ \\
\hline $\begin{array}{l}\text { Trentraent system } \\
\text { Governmental } \\
\text { Private insurance } \\
\text { Self pay }\end{array}$ & $\begin{array}{c}104 \\
0 \\
0\end{array}$ & $\begin{array}{c}100 \\
0 \\
0\end{array}$ \\
\hline $\begin{array}{l}\text { Residence } \\
\text { Rural } \\
\text { Urbam }\end{array}$ & $\begin{array}{l}79 \\
25\end{array}$ & $\begin{array}{l}76 \\
24\end{array}$ \\
\hline
\end{tabular}

Table 5.1: The age of the studied subjects ranged from 18 to less than 60 years. Most of the sample $(76 \%)$ were age from $50-<60$ years old, $(17.3 \%)$ from $40-<50$ years old, and only $(6.7 \%)$ from $18-<40$ years.

Females were more prevalent in the study sample than males, they constitute $(61.5 \%)$ of the patients, while only $(38.5 \%)$ were males. The majority of participants were married $(79.8 \%)$. Regarding the educational level the majority of the respondents were Illiterate and only $(2.9 \%)$ completed university education.

Concerning patient's occupation the study also showed that out of 104 participants only $22 \quad(21.1 \%)$ were working. the majority of the subjects were not working $(78.9 \%)$ and more than half of them were house wife $(58.7 \%)$.

Regarding the residence the majority of the subjects lived in rural areas $(76 \%)$ and only $(24 \%)$ lived in urban areas.
Table (5.2): Health related data of the study population $($ No $=104)$ :

\begin{tabular}{|l|c|c|}
\hline \multirow{2}{*}{ Items } & No & \% \\
\cline { 2 - 3 } & $\mathbf{N}=\mathbf{1 0 4}$ & $\mathbf{1 0 0}$ \\
\hline Type of AF : & & \\
Paroxysmal & 4 & 3.8 \\
Persistent & 17 & 16.3 \\
Permanent & 83 & 79.8 \\
\hline Duration of & & \\
warfarin use & 24 & 23.1 \\
$\quad<1$ year & 28 & 26.9 \\
1-<3 year & 15 & 14.4 \\
3-<5 year & 22 & 21.2 \\
5-<10 year & 15 & 14.4 \\
$\geq 10$ years & & \\
\hline $\begin{array}{l}\text { Past history of } \\
\text { hemorrhage }\end{array}$ & 24 & 23.1 \\
Yes & 80 & 76.9 \\
No & & \\
\hline $\begin{array}{l}\text { Past history of } \\
\text { stroke }\end{array}$ & 10 & 9.6 \\
Yes & & 90.4 \\
No & & \\
\hline
\end{tabular}

Table 5.2: show a health related data among study participants. Regarding diagnosis $(79.8 \%)$ of the participants diagnosed with permanent AF, (16.3\%) diagnosed with persistent $\mathrm{AF}$, but just $(3.8 \%)$ of participants diagnosed with paroxysmal AF. Regarding complications $23.1 \%$ of participants reported previous bleeding from warfarin and $9.6 \%$ of participants reported previous stroke events.

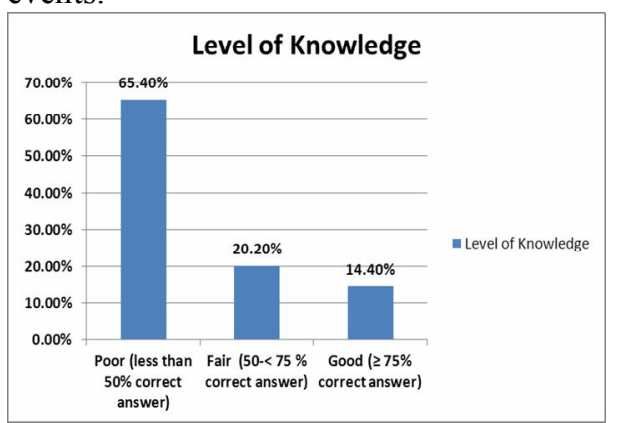

Figure (5.1): Distribution of patients on warfarin according to knowledge level. Mean total score $(9.9 \pm 6.32)$. 
Figure 5.1: shows the percentage of knowledge level about warfarin among studied AF patients and the mean score of participants who reported correct responses to items related to warfarin knowledge. knowledge level were classified into 3 levels (poor, fair, good)
.In the studied group $65.4 \%$ had poor knowledge level and only $14.4 \%$ had good level. The total score for healthcare knowledge about warfarin was $9.9 \pm 6.32$ (range 0-24). The total knowledge score was at poor level

Table (5.3): Distribution of populations with a correct response about warfarin (No=104):

\begin{tabular}{|c|c|c|}
\hline Item & No & $\begin{array}{l}\text { Percentage } \\
(\%)\end{array}$ \\
\hline $\begin{array}{l}\text { Can missing one dose of Coumadin (warfarin) alter the drug's } \\
\text { effectiveness? }\end{array}$ & 75 & 72.1 \\
\hline $\begin{array}{l}\text { Can you distinguish between different strengths of Coumadin } \\
\text { (warfarin) tablets by color? }\end{array}$ & 78 & 75 \\
\hline $\begin{array}{l}\text { Should warfarin/aspirin/other anti-platelet medication be taken for } \\
\text { patients with AF? }\end{array}$ & 100 & 96.2 \\
\hline $\begin{array}{l}\text { The risks for clots formation are reduced in AF patients taking } \\
\text { warfarin/aspirin/ other anti-platelet medication? }\end{array}$ & 64 & 61.5 \\
\hline prevention of stroke is one of the purposes of warfarin therapy & 38 & 36.5 \\
\hline $\begin{array}{l}\text { Bleeding may occur in AF patients taking warfarin/aspirin/ other anti- } \\
\text { platelet medication? }\end{array}$ & 49 & 47.1 \\
\hline Chronic use of aspirin with warfarin increase risk of bleeding? & 18 & 17.3 \\
\hline $\begin{array}{l}\text { Sudden increases in vitamin } \mathrm{K} \text { intake may decrease the effect of } \\
\text { warfarin. }\end{array}$ & 9 & 8.7 \\
\hline lowering your vitamin $\mathrm{K}$ intake could increase the effect of warfarin & 9 & 8.7 \\
\hline $\begin{array}{l}\text { Occasionally eating a large amount of leafy greens vegetables while } \\
\text { taking Coumadin(warfarin) reduce the effectiveness of the Coumadin }\end{array}$ & 12 & 11.5 \\
\hline $\begin{array}{l}\text { Warfarin treatment should be mentioned if a doctor prescribes new } \\
\text { medication or plans an operation }\end{array}$ & 60 & 57.7 \\
\hline The INR is a test of blood clotting & 97 & 93.3 \\
\hline $\begin{array}{l}\text { The purposes of monitoring INR are to adjust dose of anticoagulant \& } \\
\text { prevent complications (bleeding) }\end{array}$ & 47 & 45.2 \\
\hline Do you know Target INR level & 23 & 22.1 \\
\hline Is it necessary to monitor INR when taking warfarin & 58 & 55.8 \\
\hline Do you know your Value of current INR & 18 & 17.3 \\
\hline Do you know date of next INR check & 76 & 73.1 \\
\hline $\begin{array}{l}\text { Each time you get your PT/INR checked should you let your DR know } \\
\text { if you missed any dose of coumadine? }\end{array}$ & 29 & 27.9 \\
\hline $\begin{array}{l}\text { Foods such as (Broccoli, lettuce, watercress, bean) can affect INR } \\
\text { level. }\end{array}$ & 14 & 13.5 \\
\hline Foods rich with Vitamin K include (cabbage, spinach, peas, parsley). & 10 & 9.6 \\
\hline $\begin{array}{l}\text { Medications which can affect INR level include (antibiotics - herbal } \\
\text { supplements-vitamin K, vitamin E, panadol,aspirin)? }\end{array}$ & 32 & 30.8 \\
\hline $\begin{array}{l}\text { signs/symptoms caused by excessive anticoagulation include } \\
\text {-Nosebleeds } \\
\text {-Dark red or brown urine } \\
\text { - Excessive menstrual bleeding or bleeding } \\
\text { between } \\
\end{array}$ & $\begin{array}{l}37 \\
38 \\
34\end{array}$ & $\begin{array}{l}35.6 \\
36.5 \\
32.7\end{array}$ \\
\hline
\end{tabular}


Table (5.4): shows correlation between knowledge level and sociodemographic characteristics. There were no statistically significant differences in mean warfarin knowledge scores between married and unmarried (X2 $=7.469, \mathrm{P} 0.280$ ). The mean knowledge scores in males were significantly higher than females (X2 $=6.115, \mathrm{P}$ 0.047) . The mean warfarin knowledge scores of the subjects in the highest education group were significantly higher than those of the subjects in the lowest education $\operatorname{group}(\mathrm{X} 2=33.121, \mathrm{P} \leq$ 0.000 ). Middle age and young adults had significantly higher knowledge score than older adults (X2 $=10.745, \quad \mathrm{P} \quad 0$. 030).subjects who lived in urban areas had higher knowledge scores than those lived in rural areas $(\mathrm{X} 2=12.431, \mathrm{P} \leq$ 0.002 ).subjects who work had higher knowledge scores than those who didn't work $(\mathrm{X} 2=19.055, \mathrm{P} \leq 0.000)$.

Table(5.5): shows correlation between knowledge level and health related data. The mean knowledge scores of the subjects with long duration of warfarin use were significantly higher than those of the subjects with short duration of warfarin use (X2 =16.029, $\mathrm{P} \leq 0.042$ ). Patients with past history of bleeding from warfarin had significantly higher knowledge scores than patients with no previous bleeding (X2 $=9.919, \quad \mathrm{P} \leq \quad 0.007)$. There was no significant correlation between knowledge level and type of AF or previous stroke events.

Table (5.4): Relationship between knowledge level and sociodemographic characteristics of studied populations $(\mathrm{No}=104)$

\begin{tabular}{|c|c|c|c|c|}
\hline $\mathrm{C}_{\text {Social characterictice }}^{\text {K level }}$ & $\begin{array}{c}\text { Poor } \\
\text { No }(\%)\end{array}$ & $\begin{array}{c}\text { Fair } \\
\text { No }(\%)\end{array}$ & $\begin{array}{c}\text { Good } \\
\text { No }(\%)\end{array}$ & $\begin{array}{c}\text { Significance } \\
\text { test }\end{array}$ \\
\hline $\begin{array}{ll}\text { Sex } & \\
& \text { Male (40) } \\
& \text { Female (64) }\end{array}$ & $\begin{array}{l}22(55) \\
46(71.9)\end{array}$ & $\begin{array}{l}8(20) \\
13(20.3)\end{array}$ & $\begin{array}{l}10(25) \\
5(7.8)\end{array}$ & $\begin{array}{l}X^{2}=6.115 \\
P 0.047\end{array}$ \\
\hline $\begin{array}{l}\text { Age group } \\
18-<40(7) \\
40-<50(18) \\
50-<60(79)\end{array}$ & $\begin{array}{l}5(71.4) \\
7(38.9) \\
56(70.9)\end{array}$ & $\begin{array}{l}0(0.0) \\
8(44.4) \\
13(16.4)\end{array}$ & $\begin{array}{l}2(28.6) \\
3(16.7) \\
10(12.7) \\
\end{array}$ & $\begin{array}{l}X^{2}=10.745 \\
P 0.030\end{array}$ \\
\hline $\begin{array}{l}\text { Social status } \\
\text { Single (5) } \\
\text { Married (83) } \\
\text { Divorced (1) } \\
\text { Widow (15) }\end{array}$ & $\begin{array}{l}4(80) \\
53(63.9) \\
0(0.0) \\
11(73.3)\end{array}$ & $\begin{array}{l}0(0.0) \\
19(22.9) \\
1(100.0) \\
1(6.7)\end{array}$ & $\begin{array}{l}1(20) \\
11(13.3) \\
0(0.0) \\
3(20.0)\end{array}$ & $\begin{array}{l}X^{2}=7.469 \\
P 0.280\end{array}$ \\
\hline $\begin{array}{l}\text { Education } \\
\text { Illiterate (63) } \\
\text { Read \&write(20) } \\
\text { Secondary (18) } \\
\text { University (3) }\end{array}$ & $\begin{array}{l}51(81) \\
9(45.0) \\
8(44.4) \\
0(0.0)\end{array}$ & $\begin{array}{l}9(14.3) \\
7(35.0) \\
5(27.8) \\
0(0.0)\end{array}$ & $\begin{array}{l}3(4.7) \\
4(20.0) \\
5(27.8) \\
2(100.0)\end{array}$ & $\begin{array}{l}X^{2}=33.121 \\
P \leq 0.000\end{array}$ \\
\hline $\begin{array}{l}\text { Working status } \\
\text { Working }(21) \\
\text { Notworking }(83) \\
\end{array}$ & $\begin{array}{l}7(33.3) \\
61(73.5) \\
\end{array}$ & $\begin{array}{l}5(23.8) \\
16(19.3) \\
\end{array}$ & $\begin{array}{l}9(42.9) \\
6(7.2) \\
\end{array}$ & $\begin{array}{l}X^{2}=19.055 \\
P \leq 0.000\end{array}$ \\
\hline $\begin{array}{l}\text { Residence } \\
\text { Rural (79) } \\
\text { Urban (25) }\end{array}$ & $\begin{array}{l}56(70.9) \\
12(48.0)\end{array}$ & $\begin{array}{l}17(21.5) \\
4(20.0)\end{array}$ & $\begin{array}{l}6(7.6) \\
9(36.0)\end{array}$ & $\begin{array}{l}X^{2}=12.431 \\
P \leq 0.002\end{array}$ \\
\hline
\end{tabular}


Table (5.5): Relationship between knowledge level and health related data of studied populations $(\mathrm{No}=104)$

\begin{tabular}{|c|c|c|c|c|}
\hline Variables measured & $\begin{array}{l}\text { Poor } \\
\text { No }(\%)\end{array}$ & $\begin{array}{l}\text { Fair } \\
\text { No }(\%)\end{array}$ & $\begin{array}{l}\text { Good } \\
\text { No }(\%)\end{array}$ & Significance test \\
\hline $\begin{array}{l}\text { Type of AF : } \\
\text { Paroxysmal (4) } \\
\text { Persistent (17) } \\
\text { Permanent (83) }\end{array}$ & $\begin{array}{l}2(50) \\
12(70.6) \\
54(65.1)\end{array}$ & $\begin{array}{l}2(50) \\
2(11.8) \\
17(20.5)\end{array}$ & $\begin{array}{l}0(0.0) \\
3(17.6) \\
12(14.4)\end{array}$ & $\begin{array}{l}X^{2}=3.278 \\
P 0.513\end{array}$ \\
\hline $\begin{array}{l}\text { Duration of warfarin use } \\
<1 \text { year }(24) \\
1-<3 \text { year }(28) \\
3-<5 \text { year }(15) \\
5-<10 \text { year }(22) \\
\geq 10 \text { years }(15)\end{array}$ & $\begin{array}{l}17(70.8) \\
14(50.0) \\
13(86.6) \\
17(77.3) \\
7(46.7)\end{array}$ & $\begin{array}{l}4(16.7) \\
11(39.3) \\
1(6.7) \\
2(9.1) \\
3(20.0)\end{array}$ & $\begin{array}{l}3(12.5) \\
3(10.7) \\
1(6.7) \\
3(13.6) \\
5(33.3)\end{array}$ & $\begin{array}{l}X^{2}=16.029 \\
P 0.042 \\
M C 0.041\end{array}$ \\
\hline $\begin{array}{l}\text { Bleeding } \\
\text { Yes }(24) \\
\text { No }(80)\end{array}$ & $\begin{array}{l}10(41.7) \\
58(72.5)\end{array}$ & $\begin{array}{l}10(41.7) \\
11(13.75)\end{array}$ & $\begin{array}{l}4(16.6) \\
11(13.75)\end{array}$ & $\begin{array}{l}X^{2}=9.919 \\
P 0.007 \\
\text { MC } 0.006\end{array}$ \\
\hline $\begin{array}{l}\text { Stroke } \\
\text { Yes }(10) \\
\text { No }(94)\end{array}$ & $\begin{array}{l}6(60) \\
62(66)\end{array}$ & $\begin{array}{l}3(30) \\
18(19.1)\end{array}$ & $\begin{array}{l}1(10) \\
14(14.9)\end{array}$ & $\begin{array}{l}X^{2}=0.726 \\
P 0.696\end{array}$ \\
\hline
\end{tabular}

\section{Discussion:}

Atrial fibrillation (AF) is the most common arrhythmia in clinical practice (11). Atrial fibrillation is a major risk factor of stroke with approximately every fifth stroke is due to AF. Stroke in AF is often severe and results in long-term disability or death ${ }^{(12,13)}$

Stroke prevention in atrial fibrillation (AF), most commonly with warfarin, requires maintenance of a narrow therapeutic target (INR 2.0 to 3.0). Patients that spent at least $70 \%$ of their time in therapeutic range had a $79 \%$ reduced risk of stroke compared to patients with $\leq 30 \%$ of time in range ${ }^{(4)}$. This narrow therapeutic range is often difficult to achieve due to the many factors that can affect INR control such as food intake, other medications and alcohol intake ${ }^{(1)}$.

Warfarin therapy requires frequent monitoring and dose adjustments to maintain anticoagulation within a narrow therapeutic window. To ensure safe and effective use, it is vital that patients have a sound understanding of warfarin. Research suggests where patients have a greater knowledge of warfarin therapy, INR values are more often within the target therapeutic range (Tang et al, 2003) ${ }^{(7)}$. However, AF patients often exhibit limited knowledge of their condition and their anticoagulant therapy ${ }^{(14,36)}$. Therefore this study was conducted to determine AF patient's knowledge about using (warfarin) in Egypt. Discussion of results will be presented in the following sequence: knowledge about warfarin, factors affecting knowledge level.

The findings of this study showed that the total mean score of warfarin knowledge among the subjects were at the poor level. In the present study about two thirds of the studied subjects had poor 
level and only less than one quarter had good knowledge about warfarin.

This result agrees with a study conducted at malaysia and hongknog by (Tang et al, 2003; Matalqah etal, 2013) ${ }^{(7,16)}$ which reported that mean total score were at poor level and only less than quarter of patients had good knowledge level about warfarin. Other studies revealed that between $50-80 \%$ of patients having poor knowledge about important basic aspects of warfarin ${ }^{(14,10)}$. In contrast (Baker et al, 2011) ${ }^{(19)}$ found that about three quarters of respondents had good knowledge about warfarin.

In the present study less than two thirds of participants identified the general purpose of the medication as "it reduce risk for clots" but only one third could report that reducing the risk for stroke was the specific reason they were treated with warfarin .

The same finding of poor knowledge that warfarin reduce risk for stroke was reported in other studies conducted by (Tang etal, 2003 (40\%); St-Louis \& Robichaud- Ekstrand 2003 (38\%)) ${ }^{(7,18)}$. In contrast (Parker et al, 2007) ${ }^{(21)}$ reported that $83 \%$ of participants were aware that too little Coumadin could cause stroke.

Three quarters of the study respondents can distinguish between different dosage forms by color.

This is in accordance with a previous survey that took part by (Yassien etal, 2012) in Jordan (22). In contrast this findings is in contradiction to another study conducted at Malaysia by (YAHAYA etal ,2009) ${ }^{(23)}$ who indicated that approximately two-thirds of respondents had poor knowledge of different tablet dosage forms and their strength.

Regarding warfarin complications the present study reported that less than half of participants know that warfarin may cause bleeding.
This study finding is in agreement with results of other studies (Lane etal, 2006); Nadar etal, 2003) ${ }^{(14,15)}$ which reported that majority of patients were not aware of bleeding risks associated with warfarin.In contrast another study conducted in Finland by (Koponen etal, 2007) (24) reported that more than four fifths know that warfarin increase risk of bleeding.

This study shows also that majority of patients lack knowledge about warning signs of excess anticoagulation and interactions between warfarin and over the counter preparations and interactions between warfarin and VIT K products.

This is in accordance with results reported by others (Lip etal ,2002; St-Louis \& Robichaud- Ekstrand ,2003; McCabe etal, 2008; Yassien etal, 2012; YAHAYA etal, 2009) ${ }^{(20,18,17,22,23)}$.

Most participants know that INR is a test for blood clotting but less than half reported that they know purpose of monitoring INR and only just over the half reported that it is necessary to monitor INR.

On the same line lower results reported in other studies conducted in china by (Xu etal, 2010 ) and Jordan by (Yassien etal,2012)which report that $22 \%$ \& less than $30 \%$ of participants know purpose of monitoring $\operatorname{INR}^{(26,22)}$. In contrast higher results were reported in another study conducted by (Koponen etal, 2007) ${ }^{(24)}$ in which $77 \%$ of participants know purpose of INR monitoring.

In addition also the present study reported that majority of patients lack knowledge about target INR, current value of INR.

This is in accordance with another study conducted at china by (Xu etal, 2010) ${ }^{(26)}$ reported that only about half of participants know target INR. Another study also conducted at Hong Kong by (Lee etal, 2012) ${ }^{(27)}$ reported that only $36 \%$ know their INR level. In contrast another study conducted by (McCabe etal, 2008) 
(17) in USA reported that majority of patients know target and current value of INR.

Regarding sex of studied subjects and warfarin knowledge level, it was observed that males had significantly higher knowledge scores than females.

This finding can be explained by the fact that illiteracy increase among females than males and is contributed to the culture of most people living in rural areas in Egypt and their preference for young females to get married in young age and be available for the family and this was reflected in the study results by the higher percentage of illiteracy among female subjects. Egypt's total number of illiterates aged 10 years or more has exceeded 16 million in 2012, with approximately 10.3 million of them being females, a recent study conducted by the Central Agency for Public Mobilisation and Statistics (CAPMAS, 2012) ${ }^{(28)}$.This is in accordance with a study conducted at Finland by (Koponen etal , 2007) ${ }^{(24)}$ which reported that females were least knowledgeable about AF and anticoagulation than males. In contrast other studies conducted at malaysia and china by (YAHAYA etal, 2009; Matalqah etal, 2013; Bounda etal, 2013) ${ }^{(23,16,30)}$ reported that no difference was found for warfarin knowledge scores between males and that of females

Regardless of social state the study findings revealed no statistically significant differences in mean warfarin knowledge scores between married and unmarried.

This result is in accordance with other studies conducted by (Eugene \& Bourne, 2013; Xu etal, 2010) ${ }^{(31,26)}$ which revealed no significant statistical difference among the knowledge level of respondents based on marital status.

As regard age and its relation to knowledge of the studied subject it was found that the younger the age of the studied subjects the more knowledge he or she had and the difference was statistically significant. This may be related to that the capacity to understand and communicate is good among young adult and middle age groups but reduced in older groups due to cognitive impairment.

This result is in accordance with other studies conducted at malaysia and china and canada by (YAHAYA etal, 2009; Bounda etal, 2013;Rahmani etal , 2013) $(23,30,34)$ which reported that younger patient had higher warfarin knowledge scores than elderly. In contrast (Zungu etal ,2009) ${ }^{(33)}$ revealed no significant statistical difference among the knowledge level of respondents on hypertension based on age.

As for education the subjects who had higher level of education reported more knowledge about warfarin compared to those with low educational level and the difference was statistically significant. this could be explained by the fact that respondents who had at least primary educational status have higher chance of exposure to different information education material (I.E.C) like leaflet, manual and that they have no barriers in communicating with the health care team beside their potential to grasp information's already communicated (Naglaa \& mohamed 2010) ${ }^{(25)}$.

This result is in agreement with other studies conducted at USA and malaysia by (McCabe etal, 2008;YAHAYA etal, 2009) $(17,23)$ reported higher warfarin knowledge scores among patients with higher education. In addition other two studies conducted at Egypt by (Elashry , 2010) and (Hassan , 2009) ${ }^{(29,32)}$ which reported that the more educated the study subjects the more he $\backslash$ she had good knowledge.

Furthermore regarding to occupation the results of this study revealed that patients who work reported higher knowledge about atrial fibrillation in contrast to housewives and the difference was statistically significant. 
In accordance other studies conducted by (Bounda etal, 2013 ;Matalqah etal, 2013) ${ }^{(30,16)}$ among patients on warfarin , reported significant correlation between occupation and knowledge. In contrast another study conducted at Egypt by (Hassan , 2009) (32) among diabetics reported no significant relation between knowledge level and occupation.

As for residence results of this study revealed that patients who lived in urban areas had higher knowledge scores than those lived in rural areas and the difference was statistically significant. In contrast another study conducted at Egypt by (Hassan , 2009) (32) among diabetics reported no significant relation between knowledge level and residence.

As regard to the relation between knowledge of the studied subject and duration of warfarin use it was found that patients who had longer duration of warfarin use had greater knowledge.

This result is congruent with a study conducted at Malaysia and hongkong by (Matalqah etal, 2013; Tang et al, 2003) $(16,7)$ which reported that longer duration of warfarin use is associated with higher knowledge scores. In contrast another study conducted at Finland by (Smith etal, 2010) ${ }^{(8)}$ reported that no correlation was found between duration of therapy and knowledge about warfarin.

As regard to relation between previous history of bleeding and warfarin knowledge level it was found that Patients with past history of bleeding from warfarin had significantly higher knowledge scores than patients with no previous bleeding. In contrast another study conducted at Canada by (Rahmani etal, 2013) (34) reported that no relation was found between warfarin knowledge level and bleeding events.

As for previous thrombosis events this study revealed that no relation was found between knowledge score and previous stroke events. This result is in congruent with other study conducted at Canada by (Rahmani etal, 2013) ${ }^{(34)}$ which reported that no association was found between oral anticoagulant knowledge and previous thrombosis events.

The lack of knowledge and understanding of warfarin and INR test demonstrated by the patients in the present study at baseline may reflect the paucity of information and explanation given to the patient by their physician and other health professionals, due to the time constraints of busy outpatient clinics and the dearth of available information. Warfarin patients should be provided with better warfarin counseling to increase and enhance their warfarin and INR knowledge and enhance INR control. Being better educated about their condition and treatment may improve clinic attendance, drug compliance and possibly lead to patients using the consultation time for questions, explanations and clarification of any concerns they may have.

\section{Conclusion:}

Based on the finding of the present study, it can be concluded that about two thirds of participants had poor knowledge about warfarin .good knowledge was found only in less than one quarter of participants. The level of knowledge was found to be good in males than in females, in the young age groups than the old age group, in those with higher level of education than those with lower level of education and in patients with longer duration of warfarin use. more informational support may be needed for women ,old age patients, illiterate patients and those newly prescribed warfarin.

\section{Recommendation}

Based on the results of the present study the following recommendations are suggested:-

- Organizing patient's centered workshops to teach about warfarin and to enhance patient's motivation to play an active role in their treatment. 
- Both literate and illiterate people tailored I.E.C materials on warfarin treatment and life style modification for AF patient and should be developed and disseminated during patients waiting time in outpatient clinic.

- Designing a training program for outpatient nurses about atrial fibrillation and its management, warfarin monitoring, and proper ways to provide health education and appropriate counseling for atrial fibrillation patients in order to improve knowledge and self management.

- Establish Health education clinic under supervision of faculty of nursing staff and in cooperation with medical and nursing staff in the hospital to give periodic health education for cardiac patients and their families, receive patient's calls for their queries between follow up visits, follow-up patients through telephone calls to further assess knowledge, reinforce education, and provide counseling for lifestyle modification activities

\section{For further research:}

- Replication of the study using a larger number of sample and various settings in Egypt with the inclusion of control group to examine the effectiveness of educational program on warfarin patient's knowledge and INR control.

\section{Conflict of interest:}

The authors declare that they have no conflict of interests.

Acknowledgments:

Thanks to all patients who took part in the study, to all the nurses and other healthcare staff on the clinics involved.

Funding:

No funding sources were provided.
References:

1. Clarkesmith DE, Pattison HM, Lip GYH , and Lane DA . 2013 ; Educational Intervention Improves Anticoagulation Control in Atrial Fibrillation Patients: The TREAT Randomised Trial. PLOS One; 8 (9): e74037.

2. Camm AJ, Kirchhof P, Lip GY, Schotten U, Savelieva I, Ernst S, Van Gelder IC, Al-Attar N, Hindricks G, Prendergast B, Heidbuchel H, Alfieri O, Angelini A, Atar D, Colonna P, De Caterina R, De Sutter J, Goette A, Gorenek B, Heldal M, Hohloser SH, Kolh P, Le Heuzey JY, Ponikowski P, Rutten FH; ESC Committee for Practice Guidelines, Vahanian A, Auricchio A, Bax J, Ceconi C, Dean V, Filippatos G, Funck-Brentano C, Hobbs R, Kearney P, McDonagh T, Popescu BA, Reiner Z, Sechtem U, Sirnes PA, Tendera M, Vardas PE, Widimsky. Guidelines for the management of atrial fibrillation: the Task Force for the Management of Atrial Fibrillation of the European Society of Cardiology (ESC). Europace 2010 ; 12:13601420.

3. Hart RG, Pearce LA, Aguillar ML (2007) Meta-analysis: antithrombotic therapy to prevent stroke in patients who have nonvalvular atrial fibrillation. Ann Intern Med ; 146: 857-867. doi: 10.7326/0003-4819146-12-200706190-00007.

4. Gallagher AM, Setakis E, Plumb JM, Clemens A, van Staa TP (2011) Risks of stroke and mortality associated with suboptimal anticoagulation in atrial fibrilaltion patients. Thromb Haemost ; 106: 968977. doi:10.1160/TH11-05-0353. PubMed: 21901239.

5. Fang MC,Machtinger EL,Wang F,Schillinger D.Healthliteracy and 
Mohamed Elsayed Hamed Elzeky et. al.

anticoagulation related outcomes among patients taking warfarin.J Gen Intern Med 2006;21:841-846.

6. Stephanie H. Wilson, Panayotis Fasseas, James L. Orford, Ryan J. Lennon, Terese Horlocker, Nina E. Charnoff, Steven Melby, and Peter B. Berger: Clinical outcome of patients undergoing non-cardiac surgery in the two months following coronary stenting. J Am Coll Cardiol, 2003; 42: 234-40.

7. Tang E, Lai C, Lee K: Relationships between patients' warfarin knowledge and anticoagulation control. Ann Pharm 2003; 37:34-39.

8. Smith DE, Borg Xuerb C, Pattison HM, Lip GY, Lane DA (2010) TRial of an Educational intervention on patients' knowledge of Atrial fibrillation and anticoagulation therapy, INR control, an outcome of Treatment with warfarin . BMC Cardiovasc Disord ;10: 21 .

9. Barcellona D,Contu P,Marongiu F,Patient education and oral anticoagulant

therapy.Haematologica 2002; 87:1081-1086.

10. Roche Nagle $\mathbf{G}$, Chambers F, Nanra J, Bouchier-Hayes D , Young S. Evaluation of patient knowledge regarding oral anticoagulants.Ir Med J 2003; 96(7):211-213.

11. Fuster V, Ryden LE, Cannom DS, Crijns HJ, Curtis AB, Ellenbogen KA, Halperin JL, Le Heuzey JY, Kay GN, Lowe JE, Olsson SB, Prystowsky EN, Tamargo JL, Wann S, Smith SC, Jr., Jacobs AK, Adams CD, Anderson JL, Antman EM, Hunt SA, Nishimura R, Ornato JP, Page RL, Riegel B, Priori SG, Blanc JJ, Budaj A, Camm AJ, Dean V, Deckers JW, Despres C, Dickstein K, Lekakis J, McGregor K, Metra M, Morais J, Osterspey A,
Zamorano JL. ACC/AHA/ESC 2006 guidelines for the management of patients with atrial fibrillation executive summary: areport of the American College of Cardiology/American Heart Association Task Force on Practice Guidelines and the European Society of Cardiology Committee for Practice Guidelines (Writing Committee to Revise the 2001 Guidelines for the Management of Patients With Atrial Fibrillation). J Am Coll Cardiol 2006; 48: 854-906

12. Kirchhof P, Auricchio A, Bax J, Crijns H, Camm J, Diener HC, Goette A, Hindricks G, Hohnloser S, Kappenberger L, Kuck KH, Lip GY, Olsson B, Meinertz T, Priori S, Ravens U, Steinbeck G, Svernhage E, Tijssen J, Vincent A, Breithardt G. Outcome parameters for trials in atrial fibrillation: executive summary. Recommendations from a consensus conference organized by the German Atrial Fibrillation Competence NETwork (AFNET) and the European Heart Rhythm Association (EHRA). Eur Heart J 2007;28:2803-2817.

13. Friberg L, Hammar N, Rosenqvist M. Stroke in paroxysmal atrial fibrillation: report from the Stockholm Cohort of Atrial Fibrillation. Eur Heart J 2010;31: 967-975.

14. Lane DA, Ponsford J, Shelley A, Sirpal A, Lip GYH (2006) Patient knowledge and perceptions of atrial fibrillation and anticoagulant therapy: Effects of an educational intervention programme The West Birmingham Atrial Fibrillation Project. Int J Cardiol; 110: 354-358.

15. Nadar S, Begum N, Kaur B (2003) Patients' understanding of anticoagulation therapy in multi- 
EVALUATION OF WARFARIN KNOWLEDGE IN PATIENTS etc..

ethnic population. J R Soc Med; 96: 175-179.

16. Matalqah LM, Radaideh K, Sulaiman SA, Hassali MA, Abdul Kader MA. 2013:An instrument to measure anticoagulation knowledge among Malaysian community: A translation and validation study of the Oral Anticoagulation Knowledge (OAK) Test .Asian Journal of Biomedical and Pharmaceutical Sciences ;3(20):30-37.

17. McCabe, P.J., Schad, S., Hampton, A., \& Holland, D.E. (2008). Knowledge and self-management behaviors of patients with recently detected atrial fibrillation. Heart Lung; 37(2):79-90.

18. St-Louis, L., \& RobichaudEkstrand, S. (2003). Knowledge level and coping strategies according to coagulation levels in older persons with atrial fibrillation. Nursing and Health Science;5:67-75.

19. Baker, W.J., Pierce, K.L., \& Ryals, C.A. (2011). INR goal attainment and oral anticoagulation knowledge of patients enrolled in an anticoagulationclinic in a Veterans Affairs Medical Center. Journal of Managed Care Pharmacy; 17(2),13342

20. Lip GYH, Kamath S, Jafri M, Mohammed A, Bareford D. Ethnic differences in patient perceptions of atrial fibrillation and anticoagulation therapy: the West Birmingham Atrial Fibrillation Project. Stroke 2002;33:238- 44.

21. Parker CS Chen Z, Price M, Gross R , Metlay JP , Christie JD , Brensinger CM, Newcomb CW , Samaha FF, Kimmel SE.. Adherence to warfarin assessed by electronic pill caps, clinician assessment, and patient reports: results from the INRANGE study. J
Gen Intern Med. 2007;22(9): 12549.

22. Yassien AM, Khataybeh OY, Aleyadeh A, Al-kurdi NE, AL ShawabkahTA . patients' experiences and knowledge about using coumarin and coagulation test. Z.U.M.J;Vol.18; N.6; November; 2012

23. YAHAYA A H M *, HASSALI M A $* *$, AWAISU $\mathbf{A}^{* * *}$, SHAFIE A A.Factors Associated with Warfarin Therapy Knowledge and Anticoagulation Control among Patients Attending a Warfarin Clinic in Malaysia. Year : 2009 ;Volume : 3 Issue : 4 : Page : 1663 1670

24. Koponen L, Rekola L, Ruotsalainen T, Lehto M, Leino-Kilpi H, VoipioPulkki LM. Patient knowledge of atrial fibrillation: 3 month followup after an emergency room visit. J Adv Nurs. 2007;61(1):51-61

25. Naglaa MA, Mohamed EM .Effectiveness Of Health Education Program for Type 2 Diabetes Mellitus Patients Attending Zigzag University Diabetes Clinic, Egypt. Egypt Public Health Assoc. Vol. 85 No. 3 and 4,2010.

26. Xu W, Sun G, Lin Z, Chen M, Yang B, Chen H\& Cao $K$. Knowledge, attitude, and behavior in patients with atrial fibrillation undergoing radiofrequency catheter ablation. J Interv Card Electrophysiol (2010) ; 28:199-207

27. Lee, VW, Tam CS, Yan BP, Yu CM, Lam YY. 2012 ;Barriers to Warfarin Use for Stroke Prevention in Patients With Atrial Fibrillation in Hong Kong Clin. Cardiol (in press). Published online in Wiley Online Library. Accessed june 2014. (wileyonlinelibrary.comDOI:10.1002/ clc. 22077 
28. Central Agency for Public Mobilisation and Statistics (CAPMAS) 2012, available at http://www.egyptindependent.com/ne ws/capmas-more-16-million illiterate people - egypt-2012. accessed may 2014.

29. Elashry NE;knowledge of end stage renal disease elderly patients regarding hemodialysis.2010 .Master thesis .faculty of nursing .Alexandria university.

30. Bounda GA, Ngarambe C, Ge WH, Yu F. Assessment and evaluation efficacy of a clinical pharmacist-led inpatient warfarin knowledge education program and follow-up at a Chinese tertiary referral teaching hospital. Arch Pharma Pract 2013; 4 :168-79

31. Eugene $V$ \& Bourne PA.2013; Hypertensive patients: knowledge, self-care management practices and challenges. J Behav Health; 2(3):259268

32. Hassan BG, factors affecting compliance of diabetic patient toward therapeutic management .2009, Master thesis .faculty of nursing .zagazig university.
33. Zungu LI, Djumbe F.R. \& Setswe, K.G. (2013). Knowledge and lifestyle practices of hypertensive patients attending a primary health care clinic in Botswana. African Journal for Physical, Health Education, Recreation and Dance, November (Supplement 1), 123-138.

34. Rahmani P, Guzman CL,Blostein MD, Tabah A,Muladzanov A, and Kahn SR .2013;Patients' Knowledge Of Anticoagulation and Its Association With Clinical Characteristics, INR Control and Warfarin-Related Adverse Events . Blood: 122 (21)

35. Tesha JJ (2006); Knowledge of stroke among hypertensive patients in selected hospitals in the Tanga Region, Tanzania. Master thesis. Faculty of Community and Health Sciences. University of the Western Cape.

36. Coelho-Dantas G, Thompson BV, Manson JA (2004) Patients' perspectives on taking warfarin: qualitative study in family practice. BMC Fam Pract; 5: 15.10.1186/1471-2296-5-15. 